\title{
U.S. Settler Colonial Climates: \\ Southern California, Hawai'i, and the Healthful Tropics
}

Henry Knight Lozano, College of Humanities, University of Exeter

h.knight-lozano@exeter.ac.uk

American Nineteenth Century History (https:/ /www.tandfonline.com/toc/fanc20/20/2)

Abstract: This article traces how Anglo-Americans invoked climatic and racial ties between Hawai $i$ and Southern California in the late nineteenth century to forecast an American settler colonial future for the islands and obviate Native Hawaiian efforts to restore native sovereignty, after white elites overthrew Queen Liliuokalani and sought annexation to the United States. This climatic binding between continental and insular spaces - present in U.S. tourist and travel writing, diplomatic correspondence, and press coverage - brings into stark relief Hawai'i's often detached status in American history and historiography. By focusing on transpacific discourses of race and climate, I seek to show how - rather than as disparate places, separated by vast watery and intellectual gulfs - Hawai'i and California were conceived in much more connected ways, as benign and (racially) healthful tropics for U.S. settler colonists in the Pacific West.

Keywords: Hawai i; California; U.S. expansion; settler colonialism; race; climate

In July 1897 a reporter for the Chicago Times-Herald travelled to Riverside, California to interview citrus grower George Dole about the proposed U.S. acquisition of Hawai i $1 .{ }^{1}$ The prospect had long engaged and divided Americans; but acutely so since a cadre of haole (white) businessmen in Hawai'i, led by lawmen Sanford Dole (George's brother) and Lorrin Thurston, four years prior had overthrown Queen Liliuokalani, declared a provisional government, and pursued annexation to the United States. Then-incoming 
president Grover Cleveland rebuffed the union, due in part to the unseemly involvement of the U.S. Minister to the Kingdom of Hawai i; in 1897, however, his successor William McKinley, working with the white oligarchy at the head of a self-proclaimed Republic of Hawai $i$, prepared an annexation treaty for Congress. Americans from Washington, D.C., to the West Coast, in legislatures and in print, debated through tropes of American exceptionalism, constitutionality, republicanism, race, and other prisms the prospect of the Hawaiian Islands becoming part of the United States. ${ }^{2}$

For the unnamed Chicago journalist, George Dole appeared a suitably qualified source to appraise the formal Americanization of Hawaici. In settler colonial fashion, Dole laid claim to the islands as his homeland and political property: born in Honolulu in 1842 to a missionary father from New England, George identified at once as an American and a "native" of the islands. Like many of the missionary sons, he became a wealthy planter as sugar developed into the economic juggernaut of the Kingdom, boosted by a reciprocity treaty with the United States in 1875. While George benefitted from the boom, he also played a part in the political upheaval that anticipated the white-led coup that ended the Kingdom. In 1887 George joined with other baole in imposing a constitution on King Kalakaua that diminished the authority of the mo $i$ (monarch), increased that of white settlers, and disfranchised thousands of Kanaka Maoli (Native Hawaiians) and all Asians. Amid Kanaka Maoli protest over this "Bayonet Constitution," Liliuokalani moved to restore long-held powers of the mo' $i$ upon her ascension to the throne. Under the leadership of Sanford and backed by U.S. Marines, white elites took up arms and forced her abdication in January $1893 .{ }^{3}$

The dubious nature of the coup, and ample evidence of Native Hawaiian support for the Queen, swayed Cleveland's decision to reject annexation. George Dole, however, 
echoing his island brethren, placed the blame entirely on the Hawaiian ruler, framing the revolution as a reactive rather than aggressive move: "If Queen Liliuokalani had carried out the pledges made by her father," he claimed, "she would be reigning to-day in peace and prosperity." Dole thus made short shrift of the depth of Native Hawaiian opposition to the white settler government. In reality, Kanaka Maoli demonstrated their resistance to the Republic of Hawaii and to U.S. annexation through militant and political activism in the 1890s. After an armed counter-revolution in 1895 which was designed to restore the native monarchy failed, a Kanaka Maoli commission in 1897 gathered thousands of native signatures against the Sanford Dole-authored annexation treaty and provided petitions that were added to the U.S. Senate record. Kanaka Maoli worked closely with U.S. senators Stephen White and Richard Pettigrew to stress their desire for national and native - sovereignty. ${ }^{4}$

Crucial to the campaign was Liliuokalani, who based herself often in Washington, D.C., speaking to U.S. senators, high society, and the press, determined to dismantle the "absurd and wicked statements" annexationists circulated against her and her people. Liliuokalani also published her account of events in early 1898: an anti-imperialist treatise masquerading as memoir in order to attract a wider readership. Hawaii's Story provided a detailed excoriation of the Republic of Hawaii and its illegitimacy. She used the Congressional Record as evidence, and encouraged readers to do the same, rather than rely on the self-serving accounts of Thurston and the Doles. Liliuokalani denounced them as "aliens" and usurpers: "a few adventurers two thousand miles from California, claiming to be both Americans and Hawaiians," but who were, in fact, trying to deceive Americans just as they had Native Hawaiians. ${ }^{5}$ 
Thus, as both Liliuokalani and George Dole demonstrated - albeit from diametrically opposed sides of the issue - the right to claim a native perspective on Hawai'i was a critical element in the political contestation over the islands. Appealing to the moral conscience of the United States, Liliuokalani reminded her readers that the "Hawaiian people" were those who were ancestrally and genealogically bound to "the children of the soil - the native inhabitants of the Hawaiian islands and their descendants." " George Dole, by contrast, also presented himself and his kin as natives (by birthplace and land ownership) who had laid the groundwork for Hawai'i to become, through annexation and immigration, a white settler homeland, and thus a community fit for attachment to the United States. This, indeed, was Dole's objective in the interview with the TimesHerald.

Thus, having attempted to swat aside both Native Hawaiian sovereignty and haole impropriety in removing the Queen, Dole listed multiple reasons why Americans should put aside their own reservations about a set of geographically remote tropical islands, primarily populated by Native Hawaiians and Asian plantation workers, and accept Hawai $i$ into the Union. Geostrategic factors were an important theme. Annexing the islands, Dole asserted, echoing Henry Cabot Lodge and other U.S. expansionists, strengthened American influence in the Pacific: the archipelago would provide an invaluable naval outpost - the "key to the northern Pacific" - and reinforce U.S. "open door" trade with Asia. ${ }^{7}$ Yet, crucially given the anti-imperial leanings of many Americans, the islands would be no imperial appendage. Dole instead sought to wed Hawaici to U.S. settler colonial and white republican identity.

Dole had left Oahu in 1889, keen for his twelve children to be educated in California; nevertheless, he foresaw a large diaspora heading the other way across the eastern 
Pacific. Although insular and located within the tropics, he explained, Hawaici was already "American in sentiment," and soon would be in substance. Zeroing in on a key area of concern for the newspaper's readers, the reporter asked: "Do you expect that Hawaii will have a considerable immigration from the states?" Dole did: both capitalists and labourers. Sugar would continue to attract investors, particularly with the political reassurance of annexation, but coffee and other crops, such as fruit, promised a good livelihood for small farmers with some cash to bring with them. Dole was far from alone in this expectation, which challenged American concerns over a tropical climate believed to undermine Anglo-American industry. As he noted, the Commissioner of Labor of the Republic of Hawaii and his counterpart in California were developing a plan to support American farmers on the West Coast to relocate to Hawai $i$. Boosted by the prospect of U.S. annexation, these social ties would gradually replace the islands' reliance upon "cheap, imported labor" from China and Japan with a white American citizenry and a diversified agricultural economy. In the process, Hawaici's future would be bound not to Asia (as he and others feared) but to the United States, and most directly to the islands' "neighboring Pacific shore": California.

Importantly, climatic and environmental ties with California - intertwined with those of race and immigration - infused this vision of an American Hawaici. The islands, according to Dole, represented an unusual tropic in being climatically fit for AngloAmericans, somewhere "a white man can work all day in the fields all through the year." Here, as we shall see, he tapped into an evolving discourse of semi-tropical climatology that had been applied, with success, to the promotion of Southern California. Closing the interview, the Chicago reporter added a few words in admiration of Dole and his adopted Riverside home. Six feet tall and as "stalwart as his hardy Maine progenitors," yet a son of tropical Oahu and now a resident of a sun-kissed corner of the continental 
American West, Dole lived an enviable life, residing "in a park of twenty acres where oranges and lemons bloom all the year around." But the environmental fertility of his California home, transformed through irrigation from desert to garden, also intriguingly called to mind Hawaici. As in Dole's life-story, the islands became interlinked with California, the pair merging in the reporter's final remarks that "the flowering of this semi-tropical clime is much like that of the isles of [Dole's] birth.” Hawai'i, he added (lest the message be missed) "is more nearly like Southern California than any other part of this land."

From this natural likeness sprung a crucial corollary. If California's semi-tropical southern counties, once the domain of Native Americans and Spanish-speaking Californios, had attracted thousands of Anglo settlers and tourists, then the Hawaiian Islands - so "nearly like" them - could follow the same destiny, to become, from an American perspective, a racially domesticated, native part of the U.S. republic. Why ever would they not?

This article traces how Americans invoked climatic and racial ties between Hawai'i and Southern California in the late nineteenth century to forecast an American settler colonial future for the islands and obviate Kanaka Maoli efforts to reject U.S. annexation and restore native sovereignty. This climatic binding between continental and insular spaces present in U.S. tourist and travel writing, diplomatic correspondence, and press pieces such as Dole's interview - brings into stark relief Hawai'i's often detached status in American history. Hawaici is typically cut out of popular and scholarly constructions of the American West. ${ }^{9}$ The archipelago, in that sense, exists in a kind of limbo in the national imagination: Americanized in fact, in law - although that legality is challenged by the Hawaiian Sovereignty Movement - yet not really accepted as part of America's 
“integral" West. Hawai'i appears as both a conceptual and a geographical outlier for those scholars who draw hard lines between U.S. continental "expansionism" (of the mid-nineteenth century) and overseas "imperialism" (of its closing years). ${ }^{10}$

Such assertions seem to stem from the flawed assumption that stepping beyond the North American continent is the key identifier to a U.S. empire, and to belie how intimately U.S. continental and insular expansionism were connected, not least through the imperatives of American settler colonialism. ${ }^{11}$ Unlike colonialism, settler colonialism posits the thorough displacement of native peoples and their sovereignty and the establishment of a permanent settler society on the land; in that sense, and again in contrast to colonialism, settler colonialism as a project converts the foreign into the domestic; the exotic into a homeland. ${ }^{12}$ As Julie Kaomea writes, although settler colonists often articulated a literal, physical "elimination" of natives - whether to be achieved through disease, displacement, violence, or some combination of all three - in practice many settler colonies “ultimately... aim to displace and replace the indigenous society's sovereignty." 13 In Hawai i, as in Southern California, this "replacement" relied not solely on discrediting native peoples and cultures, often through racial and gendered discourses, and annexing their land as private, settler-owned property, but also on projecting an inexorable white influx into foreign climates and territories. Thus, by focusing on transpacific discourses of race and climate, I seek to show how - rather than as disparate places, separated by vast watery and intellectual gulfs - Hawaici and California were conceived in much more connected ways, as benign and (racially) healthful tropics for U.S. settler colonists in the Pacific West. ${ }^{14}$

\section{Tropicality in Flux}


As scholars such as Catherine Cocks have shown, the meaning of the tropics was being contested and reframed in American culture and society in the closing years of the nineteenth century. ${ }^{15}$ Tourism and transportation developers and travel writers in California, as well as in Florida, the Caribbean, and Mexico, began to present their climates in terms of tropical or quasi-tropical lures rather than perils for white visitors. Scientific and horticultural advances emboldened U.S. promoters and authors to lay claim to the psychic and physical benefits of tropicality for overworked Americans. In doing so, they challenged decades of climatic-racial essentialism that, as Ikuko Asaka has shown, denoted the tropics as sites for black rather than white residency. ${ }^{16}$

On a technical level, this involved some geographical sleight-of-hand - most obviously in the case of California, the southern border of which lies more than 600 miles north of the Tropic of Cancer. Nevertheless, West Coast boosters employed semi-tropical metaphors pervasively, even if historians of California long seemed uncomfortable with this tropicalization, which, they argued, surely dissuaded Americans by stoking disturbing ideas of torrid climes, malarial regions, and civilizational backwardness. ${ }^{17}$ Such interpretations, however, suggest a monolithic quality to the discourse of tropicality that is historically misleading. As Cocks demonstrates, white U.S. interest in and development of places from Los Angeles to the Yucatan depended, to no small degree, upon a conceptual conquest of tropical fears with enticing tropical "gifts." 18

Scholars have not yet included Hawaici within this reconstruction of the near-tropics in the U.S. imagination, however - perhaps another indicator of a reluctance to incorporate Hawai'i within the bounds of the American West. In doing so, we overlook how tropical discourses functioned not solely in a southward, continental setting but also in westward, transoceanic contexts to promote U.S. settler colonial expansion. Americans in Hawai i 
repeatedly drew parallels with Southern California to negate white concerns over a potentially debilitating tropical climate: Hawaii, W. G. Irwin thus explained to the editor of the Boston Herald, was "no more enervating than semi-tropic California," and indeed, a much more welcoming climate than the "hot" San Joaquin valley. ${ }^{19}$ Emerging in the 1880s and 1890s, these expansionist-environmental linkages between Hawai'i and Southern California, crucially, developed alongside, and gave particular meaning to, white interventions in the island kingdom that undermined and then overthrew the Native Monarchy; they presented a kind of insular extension of semi-tropical California for white residents and tourists, and thus for U.S. settler civilization. ${ }^{20}$

An inspiration to many white Americans in Hawai $i$, the climatic and marketable invention of semi-tropical California reflected an Anglo-American displacement of native peoples and sovereignty over the previous generation. Native Americans, to be sure, contested the U.S. settler conquest of their homelands but unlike Native Hawaiians, indigenous Californians had few to no legal protections, such as international treaties or land grants, as Anglo-Americans, who were initially drawn to the gold region, moved into the southern parts of the annexed state. ${ }^{21}$ Although in 1852 the U.S. federal government signed treaties with various Native American tribes to relocate them to mountainous reservations, protests from local settlers and statesmen collapsed these plans. Southern Californian tribes such as the Pala of the San Luis Rey river region survived, but endured land confiscations and evictions as incoming Euro-Americans seized farmland, orchards, and water resources with impunity. ${ }^{22}$ Anglo-Americans also put legal and extralegal pressure on the rancho land-holdings of Californios, many of who had to mortgage their real estate to pay legal fees; when a drought devastated their cattle and compounded their financial struggles, Spanish-speaking elites lost much of their lands and their political influence. While American Indians in California were often treated more brutally, 
Californios were gradually relegated to menial roles as the regional economy shifted from ranching to horticulture, tourism, and real estate. ${ }^{23}$

Incoming travel writers, including Charles Nordhoff in the early 1870s, presented an evolutionary process of racial displacement, in which "wasteful" Native Americans and Mexicans gave way to Euro-American enterprise. Nordhoff hailed, in particular, the farm "colonies" of white settlers, such as the fifty German Americans who, in in 1857, founded the town of Anaheim after purchasing 1,165 acres from Juan Pacifico Ontiveros' rancho near the Santa Ana River; they grew vineyards and inspired other emigrants to pool their funds to purchase tracts while maintaining individual ownership of small farms. In 1873 colonists from Indiana, drawn by Nordhoff's best-selling depictions of a region offering "the blessings of the tropics without their heat, malaria, or enervating influences," purchased former rancho land in the San Gabriel Valley. Despite struggles amid the bank panic that year, the colonists formed a fruit-growers' association that funded irrigation, the building of 40 houses, and the planting of 10,000 orange and lemon trees. Settlers from Indiana and Iowa joined them, and by 1880 their town, Pasadena, boasted schoolhouses and a Methodist and a Presbyterian Church; along with the affluent community of Riverside, it symbolized Nordhoff's notion of "the first tropical land which our race has thoroughly mastered and made itself at home in."24 Transportation links aided settler development and the growing claims to an "Americanizing" semi-tropical region: the Southern Pacific Railroad arrived in Los Angeles in 1876, with competing lines added in the 1880 s. ${ }^{25}$ Land-grant railroads and periodicals such as Semi-Tropic California cultivated an environmental imagery to inform readers that, once overlooked in favor of the gold country, Southern California offered "greater inducements to people seeking new homes in the West" than any other region. ${ }^{26}$ 
Writers presented a kind of "island on the land," sun-kissed but not debilitating: "semitropical less by its latitude than by its physical geography," as tourist W.M.C. wrote in 1886, charting a crescent of coastline from Point Loma to Point Arguelo, which, shielded by mountains, "enjoys a climate tempered by the sea breeze and...solar heat...to a surpassing equability," and thus healthier than "torrid" tropical countries. ${ }^{27}$

These visions ruptured historic associations between tropicality and dark races. A dry, semi-tropical climate - but also, critically, one located within U.S. borders - apparently enabled the attractions of the tropics without their environmental or social dangers. ${ }^{28} \mathrm{~A}$ place without, Nordhoff wrote, an "enervating atmosphere," "the dread of malarious [sic] diseases," "the semi-barbarous habits of the people," and "often... a lawless state of society." White settlers could thus enjoy semi-tropical "productiveness" alloyed with U.S. republicanism and a "lawful" society - a racial quality apparently absent in de facto tropics. Describing a multipurpose semi-tropical California offering "health, pleasure, and residence," regional boosters thus appealed to a range of Americans, often in the same publications: health-seekers, tourists, investors, and agricultural settlers. ${ }^{29}$ Following the medical advice of climatologists, consumptives and Americans diagnosed with "nervous diseases" headed by the thousands to winter hotels in Santa Barbara, San Diego, and Los Angeles. ${ }^{30}$ Leisure activities augmented the health-seeking boom. Spurred by the popularity of Helen Hunt Jackson's 1884 novel, Ramona, a tragic romance set in the Mexican Era, boosters began to emphasize the "picturesque" remnants of Southern California's Spanish past, available to Anglo-Americans through mission-themed tours, plays, and architecture. ${ }^{31}$ Winter tourists returned to invest in land and businesses, blurring the lines between sojourner and settler, as they fuelled diversified economic growth in the region. ${ }^{32}$ 
Alongside citrus farming, the tourist and health-seeker influxes contributed to a real estate boom in Los Angeles County, where land prices rose dramatically. ${ }^{33}$ Although the speculation flared into a temporary bust, Southern California's transformation was striking: its population grew from 64,371 in 1880 to 201,352 in $1890 .{ }^{34}$ As significant as the scale, civic promoters stressed, was the middle-class status and perceived quality of this influx, which included large numbers of Midwestern and East Coast Americans, rather than the "undesirable" immigrants from southern and eastern Europe arriving on Atlantic shores. A few years after Californians had raised hell to close off Chinese labor immigration, a writer in Los Angeles stated approvingly of semi-tropical California that, "the character of the people who come is of as much importance as the fact of their coming." 35

Thus, by 1890 - when the U.S. census announced the continental frontier officially closed - Southern California offered a distinctive archetype of the American West as a homeland for white settlers. ${ }^{36}$ For irrigation champion William Ellsworth Smythe, semitropical California offered a model of social development for the arid Southwest. ${ }^{37}$ Settler colonial discourses of native displacement infused the region's narratives. ${ }^{38}$ Viewing the irrigated groves of Riverside owned by "gentlemen” farmers such as George Dole, Charles Keeler of the Santa Fe Railroad explained how what was once "a desert occupied by a scanty, unprogressive Mexican population... [had] been made by Saxon industry perennial gardens of verdure and bloom."39

\section{Paradise of the Pacific}

Along with Keeler, Smythe, and many others, white elites in Hawai'i watched closely the settler colonial transformation of Southern California. While they hoped to replicate the region's economic growth, ideally in a steadier fashion, they noted also Californians' 
marketing of a quasi-tropical climate for white Americans. Hawaili, of course, lay in the actual tropics. Thus the islands were more seriously tarred with Euro-American ideas of tropics as climatically destructive to white civilization: home, environmental determinist geography told, to nonwhite races, plantation agriculture, semi-free labor, and political instability. ${ }^{40}$ Whites in Hawaici thus drew inspiration from the Southland, as they observed how, through publicly and privately funded settler and tourist promotion, "Southern California and Florida have been made in this way." $" 411$ American islanders increasingly envisaged a climate-shaped "manifest destiny" to bind Hawai'i and Southern California together in a transpacific American West.

No periodical better epitomized the settler colonial efforts to claim Hawai'i's future than the Honolulu-based monthly Paradise of the Pacific. The magazine, notably, was launched soon after the Bayonet Constitution, with funding from the baole-controlled legislature. The Constitution, like Paradise, owed much to Lorrin Thurston, who took a leading role in taking down Kalakaua's authority, after the King raised the ire of white elites not only because of his perceived extravagance but because he actively promoted a resurgent Native Hawaiian identity and sovereignty in both domestic and foreign policies. ${ }^{42}$ In late June 1887, having built up a secret membership at his law offices and a militia, the Honolulu Rifles, Thurston's Hawaiian League made its move. ${ }^{43}$ The League produced a public display of martial strength and proceeded to barricade the palace and place guns in the royal grounds. ${ }^{44}$ Under blatant threat and lacking any comparable force with which to resist, Kalakaua signed a new constitution that restricted his powers as mo $\%$; it also contained the property and educational qualifications that disfranchised most Kanaka Maoli and all Asians, and expanded white political power through wider suffrage. Finally, reflecting the settler colonial desire for land, the constitution removed a guarantee that 
the King's lands were "inviolable," and thus for the first time made vulnerable the Hawaiian Crown Lands. ${ }^{45}$

Native Hawaiian outrage was swift. Kanaka Maoli held mass meetings, signed petitions, and formed the Hui Kalai'aina, which, with its own constitution and electoral platform, called for the preservation of the monarchy and lower property qualifications for voters for the Kingdom's elected House of Nobles. ${ }^{46}$ Kanaka Maoli recognized the grave threat the reconstituted government posed to their nation, not least because the Bayonet Constitution also enabled the renewal of reciprocity with the United States, but under new terms. After the coup, the settler-controlled legislature ceded to the United States the rights to Pearl Harbour - a loss of territorial sovereignty Kalakaua and thousands of Native Hawaiians staunchly opposed - which won over the divided U.S. Senate. ${ }^{47}$

Yet Thurston and his allies were desperate to win over Americans in a broader sense: by reimagining Hawai'i not as a sugar plantation society home to thousands of "coolie" workers, but as a socially and racially Americanizing territory that, as described in the pages of Paradise, offered diversified attractions and a welcoming "climate" for U.S. settlers, tourists, and investors. ${ }^{48}$ Through initially free distribution at "centers of 'tourist' travel abroad" and in U.S. Board of Trade offices, on ocean steamers, and around the islands, Paradise thus aimed to boost Hawai'i's reputation and its material wealth. It grew into the Kingdom's leading promotional periodical, with a circulation of over 6,000 copies by April 1888. The readership was promised "reliable information on all points relating to climate, natural scenery and volcanic wonders, tropic life and travel, [and] agricultural and commercial interests" - although, the periodical's business manager J. J. Williams added, "politics and personalities will be carefully avoided."49 
If such disclaimers tried to downplay the revolutionary intrigue in the islands, the periodical was plainly political in its dissemination of a Hawaiian future aligned with America and, in particular, the U.S. Pacific lodestar of California. ${ }^{50}$ From its first edition, Paradise showed the influence of California's mythmakers. Just as Nordhoff and others titled their California publications in terms of "health, pleasure, and residence," Paradise ran with the sub-heading: "Hawaii for Health, Pleasure, and Profit." 51 The change from "residence" to "profit" was notable, of course; it suggested that Americans thought of the archipelago as a site for investment and travel, rather than settlement, perhaps due to the dominance of the sugar industry at the expense of other pursuits. Nevertheless, semitropical California symbolized a way forward. Tracing the key role that climate boosterism played in that region's growth, the editor argued that Hawai'i possessed a more uniform temperature and more "balmy air" for invalids and neurasthenics. ${ }^{52}$ Yet Hawai'i needed "such men as boomed Southern California" to translate those qualities into diversified socioeconomic progress. With the imminent launch of the first steam railway on Oahu, J. M. MacDonald, a Californian in Honolulu, called for American islanders to emulate the Southland, since the islands possessed "similar conditions for sanitariums, palace hotels, fruit cultivation, and most of the enterprises that have so largely contributed toward the success of the Golden State.” In doing so, U.S. residents would cast off Hawai'i's "old and dormant conditions," including, implicitly, the native rulers they had long disparaged as an impediment to modern, republican "progress.",53

Transpacific climatic and developmental comparisons with Southern California proliferated in Paradise. ${ }^{54}$ MacDonald, for example, detailed how the "one-lunged gentlemen from blizzard-land...swelled the population of San Diego, Los Angeles, and other booming cities of the Southern counties," and would find similar recuperation in Hawai ${ }^{6} .{ }^{55}$ Their influx presaged commercial benefits but also political stability: an ideal 
for haole boosters who worried, after their armed coup, that "Hawaii can ill afford to be placed in the same category as the unquiet, revolutionary states which comprise South America." ${ }^{56}$ Far better that the islands "be placed in the same category" as U.S.

California. Hawaici might indeed claim a superior climate, yet in terms of social and economic status and "modern methods of advertising," editor W. H. Graenhalgh wrote, "we are far behind our cousins of the Pacific slope of America."

Such familial rhetoric strove, none too subtly, to bind Hawai'i to California; so did improved steamer connections. Regular round-trip service between San Francisco and Honolulu began in 1883; the Oceanic Steamship Company ran a direct steamer between the cities every four weeks. ${ }^{58}$ Improved routes could overcome, Paradise explained, Americans' reluctance to visit overseas countries. ${ }^{59}$ Indeed, the oceanic voyage promised to become "as comfortable and commonplace" as the railroads taken by thousands of Americans yearly to the Far West. Californian Charles Warren Stoddard, who penned several lyrical travel books on Hawaii, hailed the modern comfort of steam travel to Honolulu; he called on the overland tourist who is "repaid by the wonders of the west" to discover also the "wonders of the tropics" - of Hawai' $\mathrm{i}$ - becoming "so near and so accessible. ${ }^{60}$ In a material sense, steam transportation thus reinforced the conceptual ties being forged between the West Coast and Hawai i.

Yet for Americans, troubling questions remained over Hawai'i's de facto tropical latitude and its racial and political implications. Haole writers thus worked hard to depict for Anglo-Americans a tropic of benign heat, free from malarial diseases or a sapping sun. ${ }^{61}$ Presbyterian minister and writer Sereno Bishop detailed how white visitors were struck by two characteristics of Hawai'i's climate: its uniformity of temperature and the "very moderate warmth of our Islands." In Hawai'i, "full tropical heat is almost unknown," 
and so were the worst afflictions of equatorial life. Although Bishop stressed Hawai'i's unique location as mid-Pacific archipelago, he reproduced the environmental imagery of Southern California. "Here the white man easily labors all day long through the hottest season," Bishop wrote, "a fact unknown in any other land within the tropics."

Such climatic framings were overtly political in rendering Hawai'i's U.S. settler colonial destiny as natural: a continuation of - not a departure from - American continental expansion into celebrated semi-tropical climes such as Los Angeles County. William R. Castle, a missionary son, large landowner, and leading figure in the Bayonet Revolution, contributed an article to an 1892 pamphlet on the islands that similarly merged climatic and settler colonial messages. Ocean currents, he explained, cooled Hawai i, distinguishing it from other tropical countries, and making its social possibilities more like California than Asia. "Perhaps you can hardly believe it, and don't understand how it can be, for you are sure that Hawaii is in the tropics," Castle wrote. "Yes it is - just barely over the line." Yet this was a healthful tropic for whites: his own kin were living proof. "The European or American family is born and reared in Hawaii, which has excellent schools, and is not, as in India, China, and other hot countries, broken up." ${ }^{, 63}$

The healthful establishment of white families in the islands was set against the disintegration of native communities. ${ }^{64}$ Never shy to reference the numerical decline of Native Hawaiians, American islanders made clear that this was due to racial and cultural flaws on the part of Kanaka Maoli - a weakness of heredity and licentious living - not an environmental issue: the islands, in fact, particularly on their slopes, possessed a welcoming atmosphere for Euro-American habitation. In a classic example of the settler colonial type, the editors of Paradise explained that "In the near future, these islands will 
be thickly populated with white people, and...they will be healthy, happy and prosperous." The reasons were threefold:

First - there is no better climate for health and happiness on the face of the earth than this. Second - the islands were at one time densely populated by the native race. Third - the white population is on the increase while the natives are decreasing. As it is an agreeable place to live and capable of supporting a large population, why should it not be thickly settled? ${ }^{65}$

Sceptical Americans, as the periodically continually argued, only had to look to Southern California for a near-example of U.S. settler transformation of semi-tropical territory.

\section{Native Sovereignty}

Framed often in this literature as a tragically, if conveniently, vanishing presence, in similar ways to U.S. discourses of the "vanishing Indian," Native Hawaiians resisted the baole-led movement for an American Hawaici and strove to defend the Hawaiian nation and sovereignty. ${ }^{66}$ This goal took martial form in Robert Wilcox's failed 1889 revolt to overthrow the Bayonet Constitution; more often, Kanaka Maoli protested through political and peaceful channels. ${ }^{67}$ On August 16, 1890, for example, a committee of 42 Native Hawaiians, headed by a brass band, marched to the royal palace with a petition for the King to call a constitutional convention; up to his death in 1891, Kalakaua, though stripped of much of his authority, continued to exert the royal veto to frustrate the legislature. ${ }^{68}$ 
At the same time, Kanaka Maoli recognized the power of settler colonial literature in the threat to their national sovereignty. ${ }^{69}$ Native Hawaiian representatives such as Joseph Nawahi challenged the legislature's funding of Paradise of the Pacific as a vehicle supposedly for the benefit of Hawaici and Hawaiians. In a legislative session in July 1890, Nawahi did so on the grounds that there was no proof that the publication contributed directly to increasing tourist travel to the islands; privately, however, he would have been well aware of the whitening visions of Hawaici $i$ that Paradise disseminated - and which he, as a supporter of Hawaiian sovereignty, vigorously opposed. ${ }^{70}$ Tellingly, baole defenders of the bill pointed to the significance of such publications to California. Elected member of the House of Nobles Macfarlane stated that "the same thing had been employed with success in California," while Noble McCarthy spoke of the "benefit of similar publications in booming Southern California." ${ }^{, 71}$ Such arguments, of course, were music to the ears of white proponents of an American Hawaii. For the same reasons, they raised the ire of Kanaka Maoli legislators, who did not hope for Hawai'i to become a second California, where, they knew, the native population had suffered disastrously in the wake of U.S. settler and territorial conquest. ${ }^{72}$ Nawahi's colleague, Representative Kauhi, compared the bill that proposed to raise government funding of Paradise to $\$ 12,000$ per annum to a "centipede approaching a child in a cradle"; any parent "would not wait till it got at the child and bit it." Kauhi's metaphor of a centipede approaching a child reversed the sanitized tropical imagery so beloved by baole boosters, making from it a grave and foreign threat to the native body. When questioned, Kauhi informed a white supporter of the funding proposal that if "he wanted to know what harm was in the bill, let him come to his house and he would give him something to listen to all night."

Native Hawaiian opposition to white settler colonialism provided critical context to the reign of Liliuokalani, who took the throne after her brother, Kalakaua, died in 1891 
during a health-seeking trip to California. An ali i nui (high chief) born in 1838, Liliuokalani demonstrated the political leadership of native women in Hawaiian society, as well as the degree to which native elites developed hybrid identities that combined Kanaka Maoli and foreign missionary cultures. She attended the High Chiefs' Children's School, a "missionary boarding school designed to anglicise Hawai'i's future leaders through both formal education in English and forced separation from their adult families." ${ }^{74}$ Later, she married an American, John Dominis, who served, among other positions, in the House of Nobles and as Royal Governor of Maui. A gifted musician and writer, Liliuokalani was named heir apparent to Kalakaua in 1877; she shared her brother's faith in the native monarchy as protector of the Kanaka Maoli and their labui (nation). ${ }^{75}$

Liliuokalani was on a tour attending Queen Victoria's Jubilee when the Bayonet Revolution occurred. She rushed back to Hawaici, dismayed at the constitution that had been forced upon her brother and that transformed the meaning of citizenship in the islands, to the detriment of the native population. After she ascended the throne, Liliuokalani's priorities were to restore Native Hawaiian sovereignty in order to repel the efforts of what she termed the "missionary party" of annexationists. Kanaka Maoli backed their Queen. Liliuokalani estimated that perhaps 6,500 - or two-thirds of registered Hawaiian voters at the time - signed petitions for a new constitution. While Thurston's Hawaiian League leveled charges of corruption at Liliuokalani, citing her support for controversial lottery and opium bills, the prospect of constitutional change to restore native authority most disturbed white colonists: Liliuokalani's unerring belief in "the right of the Hawaiian people to choose their own form of government." 
When Liliuokalani proposed a constitution that reasserted the powers of the mo' $i$, Thurston and Dole's cohort, bristling at the potential loss of power to a non-white woman and the native population, saw a chance to end the monarchy once and for all. They took up arms, marched to Iolani Palace, and forced the Queen to abdicate under duress; Liliuokalani only did so in the hope that the United States would restore her authority. Crucially, and in violation of his diplomatic authority, the U.S. Minister to Hawaici, John L. Stevens, backed the coup. He called U.S. Marines in to the streets of Honolulu - ostensibly to protect "American life and property". In practice, as he knew, the U.S. military would prove pivotal to the revolution's immediate suppression of armed native resistance. ${ }^{77}$

Stevens, it is important to note, had been a contributor to Paradise and an advocate of Hawai'i's settler colonial destiny as a benign American tropic. In a letter penned two months prior, written to the U.S. Secretary of State, John Foster, Stevens called on the U.S. government to "Americanize" Hawaii and set out a plan for how to do so. Alongside annexation, the United States, he advised, should turn the Crown lands into "small lots for actual settlers and freeholders"; this would foster a major social and racial, as well as political, evolution. The result, Stevens wrote, "soon will be to give permanent preponderance to a population and a civilization which will make the islands like southern California, and at no distant period convert them into gardens and sanitariums, as well as supply stations for American commerce." ${ }^{, 78}$ The January coup gave him the opportunity to turn this dream of U.S. transpacific settler colonialism into reality.

\section{Contesting Manifest Destiny}

Many Americans were unconvinced by this logic, however. Incoming President Grover Cleveland rebuffed the contingent of haole officials of the new Provisional Government 
who hustled over to Washington, D.C., to seek annexation. Cleveland found the whole affair distasteful. He removed Stevens from his post and ordered an investigation, which, in the form of the voluminous Blount Report, backed the deposed Queen and denounced the actions of Thurston, Stevens, et al, as illegal. Cleveland fell short, however, of restoring Liliuokalani to power, as she and her supporters petitioned, ultimately leaving the status of Hawai'i in the dithering hands of Congress, where it sat, unresolved, until the election of William McKinley in 1896 brought a pro-annexationist into the White House. ${ }^{79}$

While political stasis defined the Hawaiian question in the United States in the mid1890s, a fervent cultural debate ensued over formally attaching the islands to the American West. Concern often centred on the degree to which Hawaili could be homogenized to an acceptable degree for Americans - given its insularity, its tropicality, and its racially polyglot and disturbingly Asiatic population, increasingly so as Japanese immigrants poured into the islands on labour contracts. ${ }^{80}$ Citing all these factors, U.S. opponents to annexation rejected the very notion of a healthful tropic for white settlers. ${ }^{81}$ In an article in Harper's in late 1893, former U.S. Senator Carl Schurz lambasted the many advocates of "Manifest Destiny" who, in his eyes, had taken a cherished continental ideology and mangled it to lay claim to distant overseas acquisitions, most obviously Hawai $i$. Where, he asked, had white men ever settled and sustained themselves in the tropics, relying on their own, rather than native or coolie labour? As a result, tropical countries (he cited here Latin America) vacillated between anarchy and despotism. Annexing one was not merely immoral; it was dangerous to the future of the U.S. republic, which depended on the virtue and quality of its citizens. Environment and race thus merged in the republican merits of any territory. If Canada was a desirable acquisition, Hawai i, most certainly, was not. ${ }^{82}$ Schurz's argument, as Eric T. L. Love has 
shown, captured the imagination of other Congressmen and the wider public, who doubted the legitimacy of tropical Hawaici as a U.S. territory. ${ }^{83}$ California Senator Stephen White, one of the most vocal opponents of Hawaiian annexation, marshalled these ideas in withering speeches and articles that rejected any harmonious climatic and social bond between the West Coast and the islands. ${ }^{84}$

Yet this continental scepticism only impelled the oligarchical leaders at the head of the Provisional Government - and then the self-anointed Republic of Hawaii, formed in 1894 over the opposition of Kanaka Maoli - and their supporters to double down on their propagandizing of an American settler colonial climate, akin to that of Southern California. Soon after the coup, American islanders produced visual allegories of Hawaici that negated the native population and bound the islands to California. For the 1893 Chicago World's Fair, the Southern California Bureau of Information distributed a pamphlet that depicted on its cover an idyllic Southland. Lady Liberty, holding a bough of oranges against her loins, looked benignly across a pastoral landscape that presented the region's diverse attractions to white settlers and tourists: palm trees, a Franciscan mission, an orange grove. Yet, crucially, this "semi-tropical" domain was traversed by U.S. technological modernity: a steam train and steamship, linking the region to the eastern United States and to opportunities across the Pacific. ${ }^{85}$ Paradise's editors were impressed. Given the timing, the Southern California image almost certainly inspired their new cover in May 1893, particularly since a San Francisco lithographer, H. S. Crocker, who had visited Honolulu, produced it. ${ }^{86}$ Now transported to an island setting, Lady Liberty, with her hand on a Pacific-facing globe, offered a hand of friendship to a mother and her child - a dark-haired but ostensibly white feminized Hawai' $i$ and her son, presumably the Provisional Government that had overthrown Liliuokalani. But at four months old, the prodigious youth, standing on his own two feet, offered a platter of 
fruits to Miss America, while boxes of tea, coffee, rice, and sugar sat tantalizingly within reach: a diversified array of crops that spoke to the annexationist visions of Hawai' $i$ as a kind of insular Southern California. Visit for Hawai'i's volcanoes and tropical charm, the image beckoned, but remain for a U.S. future of commercial prosperity and white civilization. ${ }^{87}$

The oligarchy's legislative agenda, meanwhile, aimed to back up such representations of a semi-tropical white republic leaving behind native and monarchical traditions. Under Dole's presidency, the Republic banned the Native Hawaiian language in education, authenticating English as the "official" tongue. It also passed laws to begin to convert the Crown lands into homesteads. ${ }^{88}$ The Dole-backed Hawaiian Land and Improvement Company advertised, on inviting terms, lands for coffee- or fruit-growing in the Hilo district on the island of Hawai'i to American settlers, who were sold an "orange country" in which a full-bearing acre would yield the same value as the same amount of land in California and Florida. ${ }^{89}$ The leaders of the Republic, at the same time, promised that annexation would end the much-lamented contract labour system. These moves spoke to their need to persuade Americans that Hawai'i was aligned to the West Coast - with its large white population and Asiatic exclusion - not to China and Japan, whence most immigrants to the islands originated. ${ }^{90}$ With decidedly mixed success, Dole's government encouraged the importation of "Caucasian" labourers - including Portuguese immigrants - in order to reduce sugar's reliance on Japanese "coolies". The sugar industry, however, continued to call for Japanese workers, fostering divisions between planter and "nonplanter" elites in the islands; in 1897 these reached crisis point, as Dole's government prohibited three shiploads of Japanese labourers from landing, prompting a formal protest from Japan that raised diplomatic tensions between the United States and Japan over Hawai $i^{91}$ 
Throughout, Thurston and Dole portrayed themselves as embattled defenders of the U.S. republican and racial flame in the mid-Pacific. "The distinguishing features of the Anglo-Saxon race is their ability to wait as well as fight," Thurston wrote, with typical modesty. ${ }^{92}$ Closer ties with California aided their cause. As George Dole flagged up in his interview, the Labor Commissioner of the Republic of Hawaici launched a program with officials in California "for white labor," to bring struggling agriculturists in the Golden State to Hawai ${ }^{i}$ as agricultural labourers and would-be independent farmers. ${ }^{93}$ Such plans attested to the growing belief that Hawaici and California were climatically as well as socially alike. Although deeply divided over the issue of Hawai'i, voices in the West Coast press joined this chorus. According to the San Francisco Chronicle in 1897, U.S. opponents to annexation based on the idea of a torrid climate were thoroughly mistaken and, in doing so, sought "to deprive Hawaii of a chance to become a white man's country." 94 The Hawaiian branches of the Sons of the American Revolution and the Grand Army of the Republic, meanwhile, issued a joint statement for their U.S. chapters and the press that bound the islands to California. "Under the security of the starry flag, skill and enterprise will work the same wonders here [in Hawaici] that they have in Southern California and the race question will soon be happily settled for the common good of both races," it declared, reassuring their countrymen that the future belonged not to Native Hawaiians and monarchs but to white settler republicans. Thus, "the process of Americanization [in Hawai i] will be rapid and complete."95

Kanaka Maoli engaged directly with America's republican ideology to resist U.S. settler colonialism and the "republic" that was foisted upon them. Although this required a delicate balance - given their aim of restoring a monarchy - Native Hawaiians made clear the fact that the Dole oligarchy palpably lacked the "consent of the governed." ${ }^{\text {"96 }}$ Nawahi 
played a leading role in the formation of the Hui Aloha Aina [Hawaiian Patriotic League], which petitioned U.S. politicians and the press. In January 1894 the Los Angeles Times printed a petition representing more than eight thousand registered Native Hawaiian voters. The signees protested the "political crime...committed [in January 1893], not only against the legitimate sovereign of the Hawaiian Kingdom, but also against the whole Hawaiian nation." They clarified that, due to the presence of U.S. Marines, the Queen had been forced to yield because she had been "unwilling...to occasion the useless bloodshed of innocent Hawaiians"; but having so "held their peace...cannot and must not be construed as evidence that [Native Hawaiians] are apathetic or indifferent, or ready to acquiesce in a wrong and bow to their usurpers." Rather, they appealed ultimately in vain - for "justice and redress" from the U.S. government to restore their monarch and nation. ${ }^{97}$

While this resistance strategy was articulated in English, designed to engage Americans, Native Hawaiians stressed their identity as Kanaka Maoli through their own language and cultural practices, including mo'olelo (story/history), which proliferated in the native press. Native editorials, poems, and prayers, Noenoe Silva writes, expressed the shared cause of the people and their leaders through their traditional bonds with the land. With his wife Emma, who played a key role in the anti-annexation movement, Nawahi, a Christian Native, started a weekly newspaper, Ke Aloha Aina, that articulated aloha 'aina - in translation, "the love for our birth land, the Islands of Hawaici" - as a cohering force in Native identity and survival during the anti-annexation struggle. ${ }^{98}$

Even as Kanaka Maoli demonstrably challenged the white oligarchy's narratives of a passive and/or vanishing native presence, McKinley's election in 1896 reinvigorated U.S. settler colonial hopes for Hawaici. The following spring, McKinley met with Thurston; in 
June the president signed a new treaty of annexation with the men at the head of the Republic of Hawaii. Both Native Hawaiian and U.S. Congressional opposition remained strong, however: while the former, through an intra-island political movement, continued to stress the illegal nature of the coup and the Kanaka Maoli desire for a restoration of the Kingdom, the latter often centred on U.S. racial, class, and environmental fears over the tropical sugar industry and "absorbing" the Asiatic population of the islands. ${ }^{99}$ Haole annexationists tried to work this to their advantage, making Japanese immigration appear a menace to white settler colonialism in the Pacific West. ${ }^{100}$ Thurston, who never failed to raise the spectre of a Japanese "peaceful invasion" of Hawaici, phrased the issue bluntly in his annexationist "handbook": ignoring completely native claims to sovereignty, he wrote, the future of the archipelago amounted to either "Annexation or Asiatics." ${ }^{\prime 101}$

Ultimately, however, it was the outbreak of the Spanish-American War in the Caribbean and in the Philippines that catalyzed the U.S. annexation of the archipelago in the summer of 1898 - achieved through the machinations of a Joint Committee Resolution, echoing the contested acquisition of Texas a half-century prior and the subject of scathing legal assessments in recent times. ${ }^{102}$ Yet the rhetoric of the Congressional decision reflected a victory for the settler colonial visions of Hawaici as a healthful tropic for white settlers, rather than for native peoples or Asian immigrants, evident in the legislative advocacy of and press support for an American Hawaici. ${ }^{103}$ Making racial and gendered appeals to Congress, the Senate Foreign Relations Committee's report highlighted the threat of Japan and of native "barbarism" to white Americans in the islands, and called upon "our Great Republic [to save] a younger sister that has established law, liberty, and justice in that beautiful land." Subverting the tropical-racial rationale of Schurz and others, the committee projected a future settler influx of white 
Americans who would displace Native Hawaiians, Chinese, and Japanese: it hailed the "effort of the Republic [of Hawaii] to fill up the public domain with white people," which was beginning to bear fruit and would surely continue under U.S. republicanism and a healthful semi-tropical climate. ${ }^{104}$

The climatic-conceptual link with Southern California was reaffirmed in the weeks after the vote. Appraising the newly annexed islands in July 1898, San Francisco's Pacific Rural Press (with tongue firmly in cheek) penned a letter written as if from California to Hawai'i. "Somewhat Tropical Suggestions," it was titled, and while the tone was light, poking fun at the lyrical claims of regional boosters, it contained a serious point: that the semi-tropical promotion of California over the previous generation had provided a valuable precursor, a rehearsal of sorts, to the creation of an American Hawaici. California, it reasoned, had experienced a few too many frosts to sustain the tropical premise much longer, particularly now that Uncle Sam had acquired an "honest semitropical suburb" in the islands (as well as in the Caribbean). Thus, "we bestow upon you one of our proudest titles - 'the American Garden of Eden,"' the Rural Press editorialized. "We have tried our best to carry the part, but we cannot undertake it longer." Yet Hawai'i's future under American rule, it went on, should be to continue along those lines, which had a proven record in remaking popular conceptions of the sun-kissed Southland. "With these well-tried properties, Hawaii, and our goodwill, you can start into the Union with a well-defined business purpose and future." ${ }^{, 105}$ American Hawai $i$, in other words, should take up the mantle of semi-tropical California: market itself as a safe tropical annex for U.S. settler enterprise and tourist leisure, and in that way become as Americanized, in time, as the celebrated Southland.

\section{Conclusion}


It is beyond the scope of this article to chart the limitations as well as the successes of these transpacific and climate-oriented settler colonial discourses after annexation. The promotion of semi-tropical tourism to U.S. Hawai $i$, to be sure, gathered apace in the twentieth century, becoming increasingly central to the "business purpose" of territorial officials and boosters, who developed strong conceptual and transportation links with Southern California in the Progressive Era. The appeal to white settlers and farmers, however, proved far more illusory. In that sense, the late Gilded Age vision of Hawai'i as an inviting tropic similar climatically but also socially to Southern California were, at best, only partially realized - and were outright failures if evaluated through the predictions of a great influx of white settlers to follow the flag.

Yet this should not blind us to their relevance within the expansionist visions that presaged annexation, when, in the late 1880s and 1890s, Anglo-Americans overthrew the Kingdom of Hawaici and exhibited the islands through a semi-tropical climate that supported white settler colonialism. By intertwining Hawai'i with Southern California in environmental and racial narratives, boosters of U.S. expansion into the Pacific emphasized continuity rather than rupture in the formal acquisition of overseas and tropical territories. Negating Native Hawaiian sovereignty, U.S. settler colonial discourses served an important role in the promotional and political actions that bound the Hawaiian Islands to California and to the American West - and still do so today.

Notes

1. "President Dole's Brother Talks of Hawaiian Islands," Chicago Times-Herald, July 25, 1897, n.p., Dole Papers, Scrapbook 76508 (1891-1903), Huntington Library, Pasadena, California.

2. In this article I refer to the U.S. annexation of Hawai'i, as it was termed at the time; scholars such as David Keanu Sai and Tom Coffman, however, employ the term “occupation,” explaining how, under 
international law, the United States' acquisition of Hawai'i was illegal. For more on the U.S. political conquest of the islands, see Sai, Ua Mau Ke Ea; Coffman, Nation Within.

3. George Dole described the revolution as "America's opportunity" in an 1893 letter in the Riverside press. See The Reflex (Riverside, Ca.), February 4, 1893, n.p., Dole Papers, Scrapbook (1831-1937) 76506, Huntington Library, Pasadena, California.

4. Silva, Aloha Betrayed, 157-59.

5. Liliuokalani, Hawaii's Story by Hawaii's Queen (Boston: Lee and Shepard, 1898), 235-6, 333, 353; Kualapai, "The Queen Writes Back," 46-7.

6. Kualapai, "The Queen Writes Back," 57. On Native Hawaiian genealogical and geographical knowledge, see Chang, The World and All the Things Upon It.

7. See, for example, Alfred Mahan, "Hawaii and Our Future Sea Power," Forum 15 (February 1893), 1-11; Henry Cabot Lodge, "Our Blundering Foreign Policy,” Forum 19 (March 1895), 8-17.

8. "President Dole's Brother," Chicago Times-Herald.

9. Scholars have demonstrated California's influence in the development of Hawai'i's sugar industry in this period: see Teisch, "Sweetening the Urban Marketplace," 17-34.

10. Friday, "Where to Draw the Line?," 282; some scholars of the American West include Hawai'i: see Wyatt, "Alaska and Hawaici," 565-602; Whitehead, "Hawai i: The First and Last Far West," 153-177; on Hawaiian sovereignty, see Kame'elihiwa, Native Land and Foreign Desires; Trask, From A Native Daughter.

11. For a recent study viewing Hawai'i as an imperial departure in American history, see Siler, Lost Kingdom.

12. On settler colonialism, see Wolfe, "Settler Colonialism," 387-409; Veracini, Settler Colonialism; Hixson, American Settler Colonialism.

13. Kaomea, "Education for Elimination," 125-127.

14. This transpacific relationship is expanded upon, temporally and thematically, in Knight Lozano, California/Hawai i Bound.

15. Cocks, Tropical Whites. Cocks' study does not include Hawai 1 i, but the promotional construction of Hawai $i$ as U.S. tourist and settler destination parallels, in much of its environmental imagery, ideas of a continental "tropical south" for white Americans in this period.

16. Cocks, "The Pleasures of Degeneration," 215-235. Although Cocks argues convincingly that these promoters "transformed climatic determinism from a pillar of white supremacy into a vehicle for reimagining the relationship between whites, the tropical environment, and nonwhite peoples in a positive light," the Southern California/Hawai'i discourse explored here highlights how evolving U.S. climatic and semi-tropical constructions also supported white settler colonialism at America's Pacific edges. For more on racial-climatic intersections in the making of the semi-tropical United States, see Knight, Tropic of Hopes; for a study of Hawai' $i$ that explores Euro-American imperial tropical-temperate discourses, see Okihiro, Pineapple Culture; on nineteenth century climatic-essentialist American and British conceptions of the tropics as sites for black labour as well as emancipated blacks, and, in turn, the "temperate" zone as belonging to free white settlers, see Asaka, Tropical Freedom.

17. Starr, Inventing the Dream, 45. For Starr, not only did California's semi-tropical promoters misrepresent the Southland's climate and vegetation - which was closer, in seasonality and aridity, to the Mediterranean - but more damningly, he argues, probably scared off Americans who saw the tropics as a white man's grave: see also Sackman, Orange Empire, 29-30, which labels these widespread promotional efforts as "counterproductive," not least because they made "Southern California seem like Hawaii". Yet it is the reverse of that statement - that Americans made Hawaici "seem like" Southern California - that stands out from the historical record.

18. Cocks, Tropical Whites.

19. "Communicated," Pacific Commercial Advertiser, January 13, 1883, 5.

20. Coffman, Nation Within.

21. Hanks, This $W$ ar.

22. Karr, "Water We Believed," 381-399.

23. Sandos, "Because He is a Liar," 86-112.

24. Nordhoff, California, n.p.; Madison, "Taking the Country Barefooted," 236-249.

25. Encouraging this settlement were railroad agents, horticultural boosters, and writers who announced that the Golden State's southern half or third (definitions varied) was "entitled to the appellation of 'SemiTropical California”': Benjamin Truman, Semi-Tropical California (San Francisco: A.L. Bancroft \& Co., 1874).

26.“Emigration," Semi-Tropic California 3, no. 1 (January 1880), 5.

27. W.M.C., "In Southern California," New York Times, June 6, 1886, 10.

28. In a similar vein, promoters of Southern California presented the region as a "New Italy," cleansed of Old World poverty and decline - and, to an extent, Catholicism - indeed often merging the semi-tropical 
and Mediterranean metaphors that overlapped in the late nineteenth century Anglo-American imagination: Knight, Tropic of Hopes.

29. Nordhoff, California, 77-100. Nordhoff's guidebook combined climatological advice for invalids and neurasthenics with farmer-oriented chapters on "semi-tropical fruit" growing and settler colonies in Anaheim and Riverside.

30. Theodore S. Van Dyke, Southern California: Its V alleys, Hills, and Streams (New York: Fords, Howard \& Hilbert 1886), 207, 215.

31. Benjamin C. Truman, "The California Missions," New York Times, December 21, 1890, 19.

32. "Pasadena's Progress," Los Angeles Herald, May 26, 1887, 8.

33. Glenn Dumke, The Boom of the Eighties in Southern California (San Marino: Huntington Library, 1944).

34. Harry Ellington Brook, The Land of Sunshine: Southern California (Los Angeles: Southern California

Bureau of Information, 1893), 6.

35. C. S. W., "Growth of Southern California," New York Times, April 7, $1888,5$.

36. Pierce, Making the White Man's West, 10-11.

37. William Ellsworth Smythe, The Conquest of Arid America [1895] (London: MacMillan \& Co., 1905), 94.

38. "Los Angeles County," Pacific Rural Press, March 29, 1886, 85.

39. Charles A. Keeler, Southern California (Los Angeles: Passenger Dept., Santa Fe Railroad, 1899), 72.

40. Asaka, Tropical Freedom.

41. "Hawaii as a Field for Tourists", Pacific Commercial Advertiser, March 11, 1887, 2.

42. Osorio, Dismembering Labui, 224.

43. Thurston, Memoirs, 137.

44. "Hawaii," Los Angeles Herald, July 14, 1887, 1.

45. Osorio, "What Kine Hawaiian Are You?” 359-79; "Affairs in Hawaii," San Francisco Call, August 27, 1890, 4; Liliuokalani, Hawaii's Story, 181-2.

46. Silva, Aloha Betrayed, 127.

47. Tate, Hawaii: Reciprocity or Annexation, 191-200.

48. Skwiot, The Purposes of Paradise, 36.

49. "Prospectus", Paradise 1, no. 1 (January 1888), 1; "Editorial," Paradise 1, no. 6 (June 1888), 4.

50. "What's in a Name?" Paradise 1, no. 1, 1; "Prosperity Re-established," Paradise 1, no. 1, 1. The first edition celebrated the renewal of reciprocity and the cession of Pearl Harbor to the United States, which together promised "the introduction of foreign capital for internal improvements, and naturally an increased attraction to the islands by all classes of people in recognition of its political and commercial importance."

51. "Ourselves," Paradise 1, no. 1, 4. Indeed, Nordhoff was listed as a contributor to Paradise and, given concerns over the motivations behind promotional literature produced by residents, cited as an example of a visiting writer who was not "an interested party."

52. "What's in a Name?" in Ibid.

53. J. M. MacDonald, "Signs of Progress," Paradise 2, no. 2 (February 1889), 4.

54. See, for example, "Shall We Have a Board of Trade," Paradise 1, no. 5 (May 1888), 4; Viator, "Over the Oahu Railroad Line," Paradise 1, no. 9 (September 1888), 2; "Our Climate," Paradise 2, no. 3 (March 1889),

1; "Hawaii for Health," Paradise 5, no. 3 (March 1892), 6.

55. J. M. MacDonald, "Hawaii as a Health Resort," Paradise 1, no. 7 (July 1888), 5.

56. "Editorial," Paradise 4, no. 12 (December 1891), 4.

57. "Editorial," Paradise 1, no. 6, 4.

58. Advertisement for Oceanic Steamship Company, Paradise 1, no. 1, 2; see also "The Steamship

Mariposa," in Ibid., 8.

59. MacDonald, "Hawaii as a Health Resort," Paradise, 5.

60. Charles Warren Stoddard, “A Tourist's Paradise,” Paradise 1, no. 8 (August 1888), 1; for his other writings on the islands, see Stoddard, A Trip to Hawaii (San Francisco: Passenger Department of the Oceanic Steamship Co., 1885); McBride, The Colonizer Abroad, 91-117.

61. Skwiot, Purposes of Paradise, 36; "Honolulu," Paradise 1, no. 12 (December 1888), 4-5. "No other tropical city in the world...can compare with Honolulu in natural and artistic beauty," Paradise stated, but it was also a "modern city, laid out upon the best American and European plans."

62. Rev. Sereno Bishop, "Hawaiian Climate," Paradise 1, no. 8, 3.

63. William R. Castle, in Hawaii, the Paradise of the Pacific and Inferno of the World (Honolulu: Hawaiian Bureau of Information, 1892), 7; see also Curtis J. Lyons, "Hawaiian Climate," Overland Monthly 25, no. 150 (June 1895), 602-612.

64. "Editorial," Paradise 1, no. 8, 2.

65. "Vacant Lands," Paradise 3, no. 1 (January 1890), 4.

66. Dippie, The Vanishing Indian. 
67. Okihiro, Pineapple Culture, 120.

68. “The Reported Hawaiian Trouble," Sacramento Daily Union, Sept. 1, 1890, 2.

69. See "Kanaka Kickers," Los Angeles Times, August 5, 1892, 4. Native Hawaiian legislators also challenged the use of significant government funds for the Thurston-backed promotion of the Volcano House Company and Oahu Railway and Land Company in the early 1890s.

70. Silva, Aloha Betrayed, 137-142.

71. "The Legislature", Daily Bulletin, July 16, 1890, 4.

72. On Kanaka Maoli travel to California and connections with Native Americans in the nineteenth century, see Chang, The World and All the Things Upon It, 161-178, 239-242.

73. "The Legislature", Daily Bulletin, July 16, 1890, 4; "Prospectus of the Reorganization of the Press

Publishing Company," Austin's Hawaiian Weekly, September 23, 1899, 10.

74. Kualapai, “The Queen Writes Back," 52.

75. Liliuokalani, Hawaii's Story, 55-6.

76. Ibid., 188, 231, 323.

77. Okihiro, Pineapple Culture, 121-127; Liliuokalani, Hawaii's Story, 242.

78. John Stevens, U.S. Minister to Hawaii, Letter to John Foster, U.S. Secretary of State, November 20, 1892, Foreign Relations of the United States, 1894, Affairs in Hawaii (Washington, D. C.: U.S. Department of State, 1894), 381. This letter was later published in the U.S. press: “The Revolution Not 'Abrupt' - ExMinister Stevens Foretold it in March of Last Year," New York Times, December 15, 1893, 5.

79. Cleaver, Grover Cleveland's New Foreign Policy, 25-61.

80. On the influx of Japanese to Hawai'i and tensions between the United States and Japan, see Morgan, Pacific Gibraltar.

81. Cleveland's Foreign Secretary, Walter Gresham, opposed annexation on these grounds also: Castle, "Tentative Empire," 89.

82. Carl Schurz, "Manifest Destiny," Harper's Monthly 18 (October 1893), 737-745.

83. Love, Race Over Empire, 73-114.

84. Stephen M. White, “The Proposed Annexation of Hawaii,” Forum 23 (Aug. 1897), 723-736.

85. Cover of Brook, The Land of Sunshine.

86. "Aloha," Paradise 5, no. 4 (April 1892), 4.

87. Cover of Paradise 6, no. 5 (May 1893).

88. Skwiot, Purposes, 141.

89. "Prospectus of the Hawaiian Land and Improvement Company, Limited," Hawaiian Star, May 11, 1895, 4; "Diversified Industries," Paradise 8:1 (January 1895), 8; “Land for Homes” Paradise 8, no. 7 (July 1895), 99.

90. "Information Abroad," Pacific Commercial Advertiser, March 9, 1896, 4.

91. Daws, Shoal of Time, 286.

92. Lorrin Thurston, Address: 'Why I am an Annexationist', Delivered by Lorrin A. Thurston at Honolulu, to the American League, on May 29, 1895, and to the Grand Army of the Republic, on Decoration Day, May 30, 1895

(Honolulu: Hawaiian Gazette Company, 1895), 5, Walter F. Frear Collection, Papers Relating to

Annexation, 1895-98, Box 2, Hawaici State Archives.

93. "For White Labor," Hawaiian Gazette, February 23, 1897, 3.

94. "The Mixed Chronicle," San Francisco Call, November 4, 1897, 6.

95. An Address by the Hawaiian Branches of the Sons of the American Revolution, Sons of Veterans, and Grand Army of the Republic to their Compatriots in America, concerning the Annexation of Hawaii (Washington DC: Gibson Bros., 1897), 7, Walter F. Frear Collection, Papers Relating to Annexation, 1895-98, Box 2, Hawaici State

Archives.

96. Silva, Aloha Betrayed, 152-3.

97. "O Ka Kanaka," Los Angeles Times, January 23, 1894, 1.

98. Silva, Aloha Betrayed, 155-6.

99. On Kanaka Maoli anti-annexation petitions in 1897-8, see Ibid.

100. John Musick, Hawaii... Our New Possessions - An Account of Travels and Adventure, with Sketches of the Scenery, Customs and Manners, Mythology and History of Hawaii to the Present (New York: Funk \& Wagnalls Co., 1898), 448, 464; "Judge Cooley's Objections," Hawaiian Gazette, June 27, $1893,6$.

101. “Japanese Invasion in Hawaii," Sacramento Daily Union, March 20, 1897, 8.

102. Economic motivations also played a critical role in annexation: Thomas J. Osborne argues that U.S. commercial expansion, rather than geostrategic conflict, served as the primary driver of U.S. annexation of Hawai'i: see Osborne, "Trade or War?,” 285-307; for an alternative interpretation that emphasizes the outbreak of war, see Bailey, "The United States and Hawaii," 552-560; on recent challenges to the legality of "annexation," see Sai, Ua Mau Ke Ea, Sovereignty Endures.

103. Love, Race Over Empire, 146-7; “The Annexation of Hawaii,” Chicago Tribune, December 6, 1894, 6. 
104. Senate Foreign Relations Committee, quoted in Love, Race Over Empire, 147.

105. "Somewhat Tropical Suggestions," Pacific Rural Press, July 23, 1898, 50.

\section{Acknowledgments}

I am grateful to Seth Archer, Tom Smith, Bruce Baker, Gary Okihiro, and Natalie Zacek, and to the anonymous reader for their insightful comments.

\section{Disclosure Statement}

No potential conflict of interest was reported by the author.

\section{Funding}

This research was supported by grant awards from the Huntington Library and the British Association of American Studies as well as funding from the Department of Humanities at Northumbria University in Newcastle-upon-Tyne.

\section{Notes on Contributor}

Henry Knight Lozano is Senior Lecturer in American History and Liberal Arts at the University of Exeter. His first book, Tropic of Hopes: California, Florida, and the Selling of American Paradise, 1869-1929 was published in 2013 and won two awards; he is also the co-editor of The Shadow of Selma (2018) and author of articles published in the Journal of American Studies and Environmental History. He is completing a forthcoming monograph, to be published with the University of Nebraska Press, that expands on key ideas and themes in the article, entitled, California/Hawair Bound: U.S. Settler Colonialism and the Pacific West, 1848-1959.

Bibliography

Asaka, Ikuko. Tropical Freedom: Climate, Settler Colonialism, and Black Exclusion in the Age of Emancipation. Durham and London: Duke University Press, 2017.

Bailey, Thomas A. "The United States and Hawaii during the Spanish-American War." American Historical Review 36 (1931), 552-560. 
Castle, Alfred L. “Tentative Empire: Walter Q. Gresham, U.S. Foreign Policy, and Hawai'i, 1893-1895." Hawaiian Journal of History 29 (1995), 83-96.

Chang, David. The World and All the Things Upon It: Native Hawaiian Geographies of Exploration. Minneapolis: University of Minnesota Press, 2016.

Cleaver, Nick. Grover Cleveland's New Foreign Policy: Arbitration, Neutrality, and the Dawn of American Empire. Basingstoke: Palgrave Macmillan, 2014.

Cocks, Catherine. "The Pleasures of Degeneration: Climate, Race, and the Origins of the Global Tourist South in the Americas.” Discourse 29, nos. 2\&3 (Spring \& Fall 2007), 215235.

Cocks, Catherine. Tropical Whites: The Rise of the Tourist South in the Americas. Philadelphia: University of Pennsylvania Press, 2013.

Coffman, Tom. Nation Within: The History of the American Occupation of Hawai $r$. London: Duke University Press, 2016.

Daws, Gavan. Shoal of Time: A History of the Hawaiian Islands. Honolulu: University of Hawai'i Press, 1968.

Dippie, Brian W. The Vanishing Indian: White Attitudes and U.S. Indian Policy. Middletown, CT: Wesleyan University Press, 1982.

Dumke, Glenn. The Boom of the Eighties in Southern California. San Marino: Huntington Library, 1944.

Friday, Chris. "Where to Draw the Line? The Pacific, Place, and the US West." In $A$ Companion to the American West, edited by William Deverell, 271-285. Malden, MA.: Blackwell Publishing Ltd., 2004.

Hanks, Richard A. This War is for a Whole Life: The Culture of Resistance among Southern California Indians, 1850-1966. Banning, CA.: Ushkana Press, 2012.

Hixson, Walter. American Settler Colonialism: A History. New York: Palgrave Macmillan, 2013.

Kame'elihiwa, Lilikalā. Native Land and Foreign Desires: Pehea La E Pono Ai? Honolulu: Bishop Museum Press, 1992.

Kaomea, Julie. "Education for Elimination in Nineteenth-Century Hawai'i: Settler Colonialism and the Native Hawaiian Chiefs' Children's Boarding School." History of Education Quarterly 54, no. 2 (May 2014), 123-144.

Karr, Steven M. “'Water We Believed Could Never Belong to Anyone': The San Luis Rey River and the Pala Indians of Southern California." American Indian Quarterly 24, no. 3 (Summer 2000), 381-399. 
Knight, Henry. Tropic of Hopes: California, Florida, and the Selling of American Paradise, 18691929. Gainesville: University Press of Florida, 2013.

Knight Lozano, Henry. California/ Hawair Bound: U.S. Settler Colonialism and the Pacific West, 1848-1959. Lincoln: University of Nebraska Press, forthcoming.

Kualapai, Lydia. “The Queen Writes Back: Lili'uokalani's Hawaii's Story by Hawaii's Queen." Studies in American Indian Literatures 17, no. 2 (Summer 2005), 32-62.

Love, Eric T. L. Race Over Empire: Racism and U.S. Imperialism, 1865-1900. Chapel Hill: University of North Carolina Press, 2004.

Madison, James H. "Taking the Country Barefooted: The Indiana Colony in Southern California.” California History 69, no. 3 (Fall 1990), 236-249.

McBride, Christopher Mark. The Colonizer Abroad: American Writers on Foreign Soil. New York \& London: Routledge, 2004.

Morgan, William. Pacific Gibraltar: U.S.-Japanese Rivalry over the Annexation of Hawai' $i$, 18851898. Annapolis: Naval Institute Press, 2011.

Nordhoff, Charles. California for Health, Pleasure, and Residence. In Nordhoff's West Coast, edited by Kaori O’Connor. London; New York: KPI, 1987.

Okihiro, Gary. Pineapple Culture: A History of the Tropical and Temperate Zones. Berkeley: University of California Press, 2009.

Osborne, Thomas J. "Trade or War? America's Annexation of Hawaii Reconsidered." Pacific Historical Review 50, no. 3 (Aug. 1981), 285-307.

Osorio, Jonathan Kay Kamakawiwo'ole. Dismembering Labui: A History of the Hawaiian Nation to 1887. Honolulu: University of Hawai'i Press, 2002.

Osorio, Jonathan Kay Kamakawiwo'ole. “What Kine Hawaiian Are You?: A Mo’olelo about Nationhood, Race, History, and the Contemporary Sovereignty Movement in Hawai'i." The Contemporary Pacific 13, no. 2 (Fall 2001), 359-79.

Pierce, Jason E. Making the White Man's West: Whiteness and the Creation of the American West. Boulder: University Press of Colorado, 2016.

Sackman, Douglas. Orange Empire: California and the Fruits of Eden. Berkeley: University of California Press, 2005.

Sai, David Keanu. Ua Mau Ke Ea, Sovereignty Endures: An Overview of the Political and Legal History of the Hawaiian Islands. Honolulu: Pu'a Foundation, 2011.

Sandos, James A. "'Because He is a Liar and a Thief': Conquering the Residents of 'Old' California, 1850-1880.” California History 79, no. 2 (Summer, 2000), 86-112. 
Siler, Julia Flynn. Lost Kingdom: Hawaii's Last Queen, the Sugar Kings, and America's First Imperial Adventure. New York: Grove Press, 2012.

Silva, Noenoe. Aloha Betrayed: Native Hawaïan Resistance to American Colonialism. Durham: Duke University Press, 2004.

Skwiot, Christine. The Purposes of Paradise: U.S. Tourism and Empire in Cuba and Hawairi. Philadelphia: University of Pennsylvania Press, 2010.

Starr, Kevin. Inventing the Dream: California through the Progressive Era. Oxford: Oxford University Press, 1985.

Tate, Merze. Hawaii: Reciprocity or Annexation. East Lansing: Michigan State University Press, 1968.

Teisch, Jessica. "Sweetening the Urban Marketplace: California's Hawaiian Outpost." In Cities and Nature in the American West, edited by Char Miller, 17-34. Reno: University of Nevada Press, 2010.

Thurston, Lorrin. Memoirs of the Hawaiian Revolution. Honolulu: Advertiser Publishing Co., 1936.

Trask, Haunani-Kay. From A Native Daughter: Colonialism and Sovereignty in Hawai'i.

Honolulu: University of Hawaici Press, 1993.

Veracini, Lorenzo. Settler Colonialism: A Theoretical Overview. London: Palgrave Macmillan, 2010.

Whitehead, John. "Hawai'i: The First and Last Far West," Western Historical Quarterly 23, no. 2 (May 1992), 153-177.

Wolfe, Patrick. "Settler Colonialism and the Elimination of the Native." Journal of Genocide Research 8, no 4 (December 2006), 387-409

Wyatt, Victoria. "Alaska and Hawaici." In The Oxford History of the American West, edited by Clyde A. Milner II, et al., 565-602. Oxford: Oxford University Press, 1994. 